Board of Governors of the Federal Reserve System

International Finance Discussion Papers

Number 614

June 1998

\title{
MULTILATERALISM AND THE ENDOGENOUS FORMATION OF PTAS
}

\author{
Caroline L. Freund
}

NOTE: International Finance Discussion Papers are preliminary materials circulated to stimulate discussion and critical comment. References in publications to International Finance Discussion Papers (other than an acknowledgment that the writer has had access to unpublished material) should be cleared with the author or authors. Recent IFDPs are available on the Web at www.bog.frb.fed.us. 


\title{
Multilateralism and the Endogenous Formation of PTAs
}

\author{
Caroline L. Freund*
}

\begin{abstract}
This paper examines the interaction between preferential trade agreements (PTAs) and multilateral tariff reduction in a model of imperfect competition. A growing literature finds that the formation of PTAs alters the incentives for and the sustainability of multilateral tariff reduction. We show that the causation is not one-sided -- multilateral tariff reduction also affects the formation of PTAs. Specifically, tariff reduction enhances the incentives to form a PTA and increases the likelihood that it is self-enforcing. Thus, each round of multilateral tariff reduction should lead to a new wave of PTAs. This may help to explain the current trend towards regionalism.
\end{abstract}

Keywords: imperfect competition, regionalism, and trade

* Economist in the International Finance Division of the Federal Reserve Board. Correspondence: caroline.l.freund@frb.gov. I am very grateful to Jagdish Bhagwati, Kyle Bagwell, and John McLaren for many useful discussions. I also benefitted from comments from Simeon Djankov, Catherine Mann, Seamus O'Cleireacain, Francisco Rivera-Batiz, and an anonymous referee. The views in this paper are solely the responsibility of the author and should not be interpreted as reflecting the views of the Board of Governors of the Federal Reserve System or of any other person associated with the Federal Reserve System. 


\section{Introduction}

Since the second world war the overall tariff level has fallen dramatically. The average manufacturing ad valorem tariff level fell from approximately 40 percent in 1948 to about 3 percent in 1998 . At the same time, the number of preferential trading agreements has increased significantly. The number of regional agreements approved under the GATT increased from just one in 1949 to more than 100 today (Figure 1). This leads one to wonder whether there is a relationship between the declining tariff level and the proliferation of PTAs.

While a growing literature has addressed the impact of PTAs on optimal tariffs and multilateral tariff reduction, ${ }^{1}$ the opposing question has not been addressed. This paper seeks to fill this gap by looking at the effect of multilateral trade liberalization on the formation of PTAs. ${ }^{2}$ We explore how multilateral tariff reduction affects the incentive to join a PTA and the associated self-enforcement mechanism. A surprising conclusion is that as the multilateral tariff level falls, the forces pulling countries away from free trade and into bilateral agreements strengthen.

To explore the relationship between multilateral tariff reduction and PTAs we extend the oligopolistic model of trade. Three countries import and export a single imperfectly competitive good. A prisoner's dilemma is created, whereby each country prefers to have a positive tariff, but the resulting trade war equilibrium is worse for all nations. Since everyone would benefit from

\footnotetext{
${ }^{1}$ See for example, Bagwell and Staiger (1997a, 1997b), Bond and Syropoulos (1996a and 1996b), Grossman and Helpman (1995), Kennan and Riezman (1990), Krugman (1992), Krishna (1998), Levy (1997), and Richardson (1993).

${ }^{2}$ Recent independent work by Ethier (1996) addresses the relationship between multilateralism and the formation of PTAs in a small country - large country model. He finds that a reform-minded small country can more easily achieve reform after linking up with a large country because the regional agreeement gives the small country a marginal advantage over other small countries in attracting foreign direct investment. When tariffs are low, the value of foreign investment is greater, making developing countries more eager to sign PTAs-even if they are required to make most of the concessions.
} 


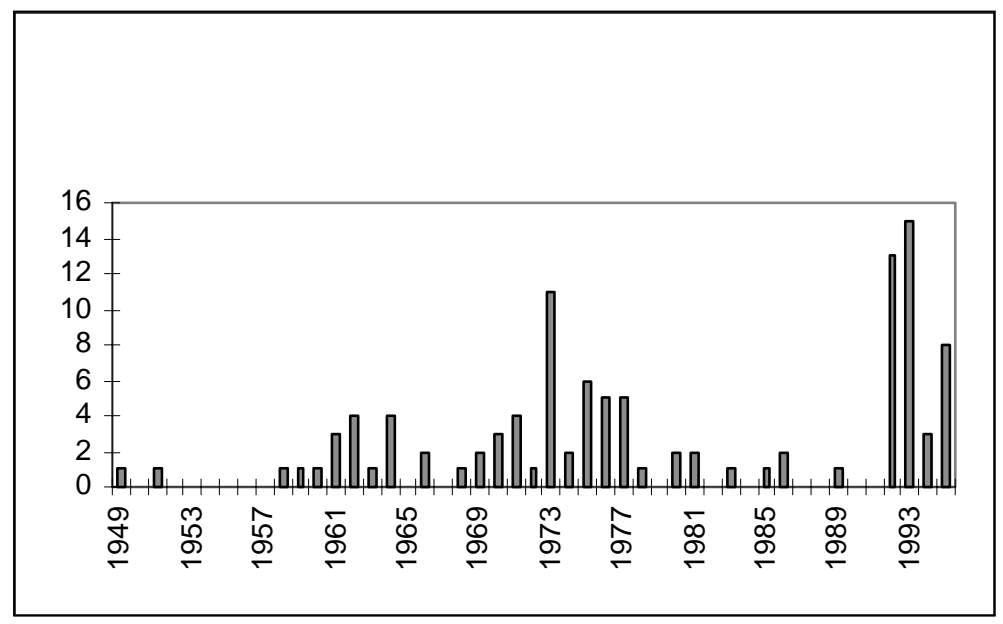

Figure 1: Number of Preferential Agreements Approved under Article XXIV. Source Bhagwati and Panagariya (1996), pp. 56-73.

tariff reduction, we examine the incentive to reduce tariffs preferentially and multilaterally. In the process, we identify the various effects that come into play, depending on which type of reduction is implemented.

We find that the welfare gain from joining a PTA is greater than the gain from a move to free trade when tariffs are low; while, the reverse is true when tariffs are high. The logic comes from the effect of tariff reduction on competition, profits, and tariff revenue. Lowering tariffs enhances competition, which leads to greater output, moving the economy closer to the efficient outcome. At high world tariff levels, this efficiency effect is large and multilateral tariff reduction, which has a greater effect on competition than preferential reduction, is better. However, lowering tariffs also means smaller profits and less tariff revenue. At overall low tariff levels, although the efficiency effect still leads to incentives for tariff reduction, preferential reduction is less costly - profits and tariff revenue fall by less. Preferential agreements effectively allow members to divert part of the profit loss that results from lower tariffs, to the third country where output contracts. This redistributive 
effect makes preferential reductions more beneficial than multilateral initiatives at low tariff levels.

Next we examine whether bilateral agreements are enforceable. We use the repeated game framework to explore the criteria for self-enforcing bilateral tariff reductions. ${ }^{3}$ An agreement is enforceable if the present value of the gain from complying with the tariff reduction forever, outweighs the gain from unilaterally installing the optimal tariff for one period and then entering the punishment phase. Punishment consists of the former PTA members imposing optimal tariffs on each other. As is always the case in this type of game, the extent of cooperation is increasing in the countries' discount rates.

We find that the feasibility of a PTA is dependent on the tariff level. As tariffs fall, a PTA is more likely to be sustainable-that is, the cutoff discount rate necessary to support the PTA is increasing in the tariff level. This follows directly from above. A PTA is most beneficial when external tariffs are low, implying the incentive to comply is high. Hence, bilateral cooperation is facilitated by multilateral cooperation and multilateral tariff reduction can make a bilateral agreement that was initially infeasible, feasible.

While the general phenomena of falling tariffs and an increasing number of PTAs are certainly evident in the world, we can also look to particular cases for consistency with the model. One example is the Common Market of the South (Mercosur); Mercosur is made up of four countries that attempted to form a union many years ago-a union which was apparently not self-enforcing. The Latin American Free Trade Area (LAFTA), established in 1960, was a failure, governments refused to enact the proposed tariff reductions and the agreement eventually collapsed. In 1991, four of the original seven members of the LAFTA formed Mercosur. This time around, the tariff

\footnotetext{
${ }^{3}$ This approach is consistent with trade policy implementation. For example, the GATT/WTO provides for coordinated retaliation in a multilateral setting. In bilateral disputes, the United States uses section 301 to threaten retaliation when faced with unfair trade restrictions abroad.
} 
reduction deadlines have in general been met and the union appears to be sustainable. Another former LAFTA member that has recently joined a PTA, which so far appears to be self-enforcing, is Mexico. Mexico joined the US and Canada in forming NAFTA in 1994. The intuition which this paper provides for the success of the new regionalism is that PTAs are easier to support and more beneficial to the member nations in the moderate tariff climate today than they were in the high tariff climate of the 1960s.

This paper is divided into four sections. Section 2 describes the static model and examines optimal tariffs. Section 3 develops the dynamic model and defines the conditions under which tariff reductions are beneficial and enforceable. Section 4 concludes.

\section{Static Model}

There is one good which is produced by a single profit maximizing firm in each country and segmented markets lead to trade in this good. There are three countries $X, Y$, and $Z$. We assume the inverse demand function, $P^{i}(Q)$, in each country is linear. Specifically,

$$
P^{i}(Q)=1-a Q^{i} \text { and } Q^{i}=x^{i}+y^{i}+z^{i}
$$

where $a$ is a constant, $Q^{i}$ is the total quantity consumed in country i, and $x^{i}$ is the quantity produced by the firm in $X$ for market $i$, and similarly for $y^{i}$ and $z^{i}$. Competition is Cournot. Profits to the firm from country $X$, in country $i, \pi^{i}$, are:

$$
\pi^{i}=x^{i} P^{i}\left(Q^{i}\right)-c x^{i}-t_{x}^{i} x^{i}
$$

where, $c$ is a constant cost of production, and $t_{j}^{i}$ is the tariff that the firm from country $j$ faces in market $i\left(t_{x}^{x}=0\right)$. 
The government's welfare function, $W$, in country $X$, is the sum of consumer surplus, producer surplus, and tariff revenue.

$$
W=U(Q)-P^{x} Q+\sum_{i=x, y, z}\left(x^{i} P^{i}-c x^{i}-t_{x}^{i} x^{i}\right)+t_{y}^{x} y^{x}+t_{z}^{x} z^{x}
$$

In equation $(3), U(Q)$ is the consumer utility from that quantity. Solving for profit maximizing quantities in each market and plugging into equation (3), we have:

$W=\frac{\left(3(1-c)-t_{y}^{x}-t_{z}^{x}\right)^{2}}{32 a}+\sum_{i=x, y, z} \frac{\left(1-c+\sum_{j=y, z} t_{j}^{i}-3 t_{x}^{i}\right)^{2}}{16 a}+t_{y}\left(\frac{1-c+t_{z}^{x}-3 t_{y}^{x}}{4 a}\right)+t_{z}\left(\frac{1-c+t_{y}^{x}-3 t_{z}^{x}}{4 a}\right)$,

where the first term is consumer surplus, the second term is producer surplus, and the last two terms are tariff revenue.

\subsection{Optimal Tariffs}

A welfare maximizing government will implement a positive tariff. ${ }^{4}$ If there are no PTAs, the government maximizes welfare, equation (4), over $t_{y}^{x}$ and $t_{z}^{x}$, taking other countries' tariffs as given. The optimal tariff that country $X$ places on goods imported from country $Y$ is:

$$
t_{y}^{x}=\frac{3(1-c)+7 t_{z}^{x}}{17}
$$

In this model, the optimal tariff in one country is not a function of the tariffs implemented abroad. Equation (5), however, shows that the optimal tariff on one trading partner is related to its tariff on the other trading partner. That is, a reduction in the tariff $X$ levies against $Z\left(t_{z}^{x}\right)$ leads to a decline in $X^{\prime} s$ optimal tariff on $Y\left(t_{y}^{x}\right)$. The intuition is that when $X$ lowers the tariff on goods from $Z$, imports from $Y$ fall, which in turn lowers both the tax base and consumer surplus. By slightly

\footnotetext{
${ }^{4}$ We rule out export subsidies by assumption.
} 
reducing the tariff on $Y$, exports from $Y$ expand, alleviating these effects. In a different kind of model, with competing exporters and perfect competition, Bagwell and Staiger (1997a) reach the same conclusion and call this the "complementarity effect" of tariff reduction.

Proposition 1 The optimal tariff a country places on one trade partner is increasing in its tariff on its other partner.

With symmetric countries, the tariff on $Y$ will be equivalent to the tariff on $Z$, resulting in an optimal tariff of:

$$
t^{*}=\frac{3(1-c)}{10}
$$

Countries in a customs union will choose the tariff that maximizes their joint welfare over their external tariff. If $X$ and $Y$ form a union they will maximize welfare, equation (3), over $t_{z}^{x}$ and $t_{z}^{y}$, simultaneously. Solving, we have:

$$
t^{c u}=\frac{5(1-c)}{19}
$$

where $t^{c u}$ is the optimal tariff that a customs union chooses.

In a free trade area, each country in the region optimizes over its own welfare with respect to the tariff on the outsider. The optimal tariff chosen by a free trade area, $t^{f t}$, containing $X$ and $Y$ is:

$$
t^{f t}=\frac{3(1-c)}{21}
$$

Because of the complementarity effect of tariff reduction, a country in a free trade area or a customs union has a lower external tariff than an individual country. The optimal tariff in a free trade area is lower than the optimal tariff in a customs union because a customs union internalizes the positive effect of the tariff, on each member's profits, in its partner country. That is, a greater external 
tariff shifts market share and profits, within the common market, to the member countries. ${ }^{5}$

While setting the optimal tariff is the strictly dominant strategy for each country in the stage game, if each country does so everyone is worse off - a prisoners' dilemma arises. The next section builds a dynamic model which allows us to determine when free trade and/or PTAs are sustainable.

\section{Dynamic model}

We use the repeated game framework as a mechanism to support bilateral tariff reduction. Since article XXIV of the GATT permits countries to form a PTA only if they eliminate all bilateral tariffs, we evaluate the sustainability of PTAs which move the participating countries to free trade. Because the focus is on the formation of a PTA, we take the initial tariff level as given and assume tariffs are symmetric for simplicity. ${ }^{6}$ The PTA must be mutually self-enforcing, where bilateral tariff elimination is enforced by a threat that participating countries will impose optimal tariffs on each other, forever, in the event of a deviation. Thus, if two countries form a PTA, it must be the case that the gains to them from committing to zero bilateral tariffs are greater than the gains from a one shot deviation and then entering the punishment phase.

The main result is that PTAs are more beneficial to member countries and are more likely to be enforceable when the external tariff level is low than when it is high. At a low tariff level, profits abroad are greater and domestic efficiency is higher than at a high tariff level. Forming a

\footnotetext{
${ }^{5}$ Similarly, Kennan and Riezman (1990) and Bagwell and Staiger (1997a) also find that FTAs have lower optimal tariffs than customs unions.

${ }^{6}$ If tariffs are not symmetric, lowering tariffs reciprocally still makes PTAs more easily enforced, but the solutions are less transparent. Additional considerations come into play, for example, the assymetry of union formation implies certain countries can more easily support the agreement and/or have more to gain. Since these are not the focus of this paper, we consider only a symmetric tariff structure.
} 
PTA expands welfare further by shifting common market profits towards member countries and by improving efficiency. The welfare level of a country in a bilateral agreement is greater at a low tariff level, implying that the incentive to comply with the agreement is higher. In addition, the incentive to cheat on an PTA and install the optimal tariff on the other member is lower when tariffs are low, making cooperation easier. However, owing to the complementarity effect, the punishment is less severe when tariffs are low, which makes forming a PTA more difficult. Still, the former effects outweigh the latter and the cutoff discount rate needed to support a PTA is lower when tariffs are low.

Some multilateral tariff reduction will be feasible if discount rates are positive. Since tariff reduction implies that a bilateral agreement becomes easier to enforce, tariff reduction directly influences trade agreement possibilities. A PTA that is not sustainable initially can become enforceable when tariffs fall.

Finally, we show that if multilateral free trade cannot be enforced starting from the trade war equilibrium neither can a move to bilateral free trade. At the Nash equilibrium, the cutoff discount rate needed to enforce multilateral free trade is lower than the cutoff discount rate needed to enforce a bilateral agreement. Hence, if free trade is not sustainable initially, neither is a bilateral agreement.

\subsection{Forming a PTA}

\subsubsection{Incentive constraint}

In this section we examine the incentive constraint a country faces with respect to participating in a PTA. If a country is better-off in a PTA then it must be the case that:

$$
W^{P T A}(0, t, 0, t, t, t) \geq W(t, t, t, t, t, t)
$$


where $W\left(t_{y}^{x}, t_{z}^{x}, t_{x}^{y}, t_{z}^{y}, t_{x}^{z}, t_{y}^{z}\right)$ is the welfare in country $X$, facing tariffs $t_{j}^{i}$ (recall $t_{j}^{i}$ is the tariff, in country $i$, on goods from country $j$ ), defined in equation (4). Equation (9) says that welfare in a PTA is greater than the welfare at the present tariff level. From equations (4) and (9), the welfare gain from moving to bilateral free trade is:

$$
W^{P T A}-W=\frac{t(6(1-c)-7 t)}{32 a} .
$$

Equation (10) is greater than zero, provided:

$$
t \leq \frac{6}{7}(1-c)
$$

which holds for all for all reasonable $t .{ }^{7}$ Thus, for any given tariff level, a country is always better off in a PTA.

Proposition 2 For all tariff levels, a country is always better-off joining a PTA.

At what tariff level does a PTA maximize welfare? Maximizing welfare with respect to the external tariff level, yields the following first order condition:

$$
\frac{d W^{P T A}}{d t \mid t_{y}^{x}=t_{x}^{y}=0}=\frac{(1-c)-11 t}{16 a}=0 .
$$

Thus, at an overall tariff level of $t=(1-c) / 11$ a region maximizes welfare. This implies that members will not desire free trade since PTA welfare is maximized at a positive overall tariff level. Moreover, there exists a positive tariff level at which the gain from joining a PTA is greater than the gain from moving to free trade.

\footnotetext{
${ }^{7}$ The optimal individual tariff is $\frac{3(1-c)}{10}$, so $t$ will always be lower than $\frac{6(1-c)}{7}$.
} 


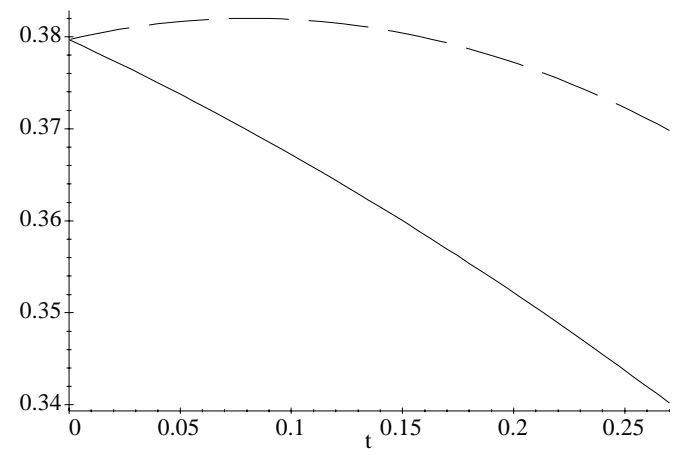

Graph 1: Welfare in a PTA vs. individual country welfare at multilateral tariff level t. $(\mathrm{a}=1, \mathrm{c}=0.1,--$ - is welfare in a PTA, - is welfare of an individual country)

For example, Graph 1 shows the welfare of a country in a bilateral agreement (the left hand side of equation (9)) and of an individual country (the right hand side of equation (9)), given the prevailing tariff level (with $c=0.1$, and $a=1$ ). Welfare is always greater for a country in a PTA than for an individual country, given the tariff level, $t$, and welfare at a low positive tariff level is greater than free trade welfare.

Proposition 3 There exists a positive overall tariff level at which the welfare of a country in a PTA is greater than its welfare at free trade. ${ }^{8}$

The intuition follows from the effect of joining a PTA on profits, tariff revenue, and consumer surplus. The net gain from forming a PTA, equation (10), can be decomposed into three parts. The first is the added welfare from getting the exports from $Z$ at a lower price (area $A$ in Figure 2); the second is the change in profits from increased output by PTA members relative to the non-member (area $C$ ); and the third is the efficiency gain (area $D$ ). The net gain is the shaded area in Figure 2. The gain is not only an efficiency gain, as is the case with a move to free trade, there is also a redistributive gain, which results from a shift in consumption away from goods produced in $Z$

\footnotetext{
${ }^{8}$ The non-member country is, however, worse-off.
} 


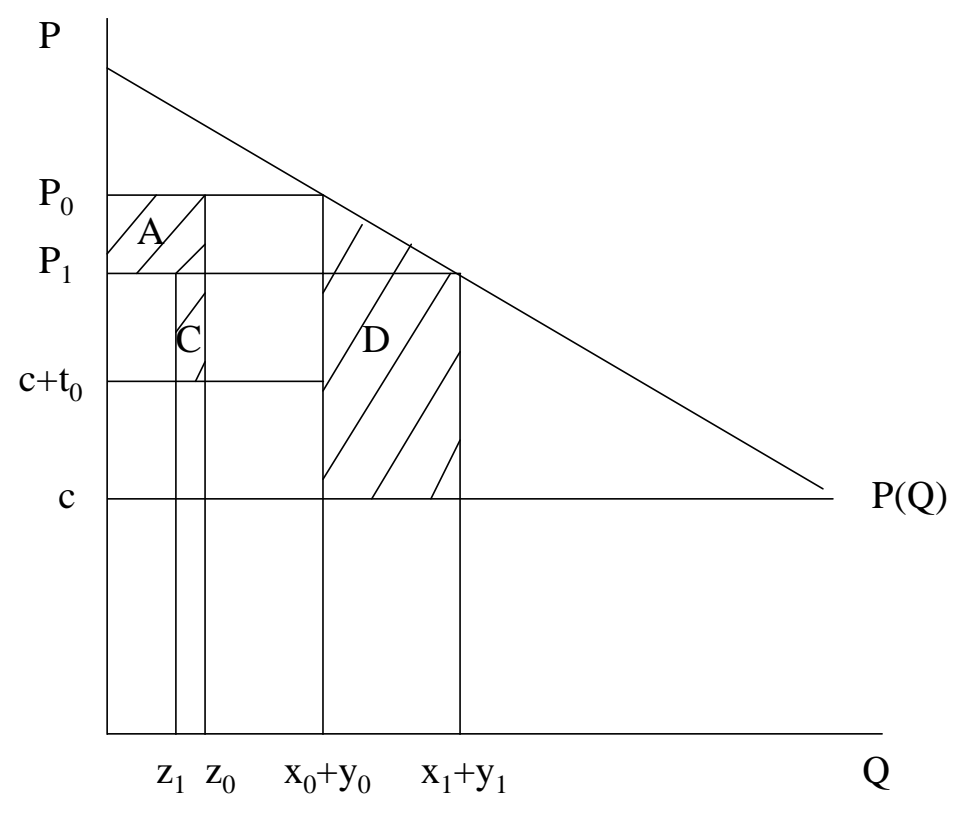

Figure 2: Preferential trade agreement

towards goods produced in $X$ and $Y$. The welfare gain in country $Y$ from forming a PTA with $X$ will, by symmetry, look identical to $X$; however, country $Z$ will suffer a loss.

At a low tariff level, the redistributive and efficiency gains from joining a PTA outweigh the gain from eliminating tariffs completely. Countries will thus prefer membership in a PTA to free trade.

\subsubsection{Enforceability}

Two countries can form a PTA provided they can commit to a bilateral tariff of zero. Starting from any point below the optimal tariff level, in order for a bilateral agreement between country $X$ and 
country $Y$ to be sustainable, the following condition must hold in country $X: 9$

$$
W\left(t^{n}, t, 0, t, t, t\right)+\sum_{\tau=1}^{\infty} W\left(t^{n}, t, t^{n}, t, t, t\right) \delta^{\tau} \leq \sum_{\tau=0}^{\infty} W(0, t, 0, t, t, t) \delta^{\tau}
$$

where $t^{n}$ is the optimal tariff on $Y$ given the tariff level, $t$, defined in equation (5), $\tau$ is the time period, and $\delta$ is the discount rate. The first term on the left hand side is the one period gain to country $X$ from deviating and installing its optimal tariff given the partner country complies. The second term is the discounted present value of the punishment phase. The right hand side is the gain from cooperating. We assume the prevailing tariff level between the non-member and the member countries is maintained in the event of a deviation. Plugging equations (4) and (5) into (13) and solving, yields:

$$
\delta \geq \frac{227 t+39(1-c)}{6(13 t+25(1-c))}
$$

Equation (14) defines the minimum discount rate necessary, given the tariff level $t$, for country $X$ to commit to a PTA. By symmetry, the same condition must hold in country $Y$.

The cutoff discount rate, $\delta$, is increasing in $t .{ }^{10}$ Graph 2 plots equation (14) (for $c=0.1$ ). It shows the cutoff discount rate that is required, at each tariff level, for the partner countries to be able to enforce a bilateral free trade agreement. Because the cutoff discount rate declines when the tariff level falls, a bilateral agreement can become feasible as a result of multilateral tariff reduction.

\footnotetext{
${ }^{9}$ We explore the enforceability constraint at the optimal tariff equilibrium in section 3.1.3.

${ }^{10}$ Specifically $\frac{d \delta}{d t}=\frac{2584(1-c)}{3(13 t+25-25 c)^{2}}$.
} 


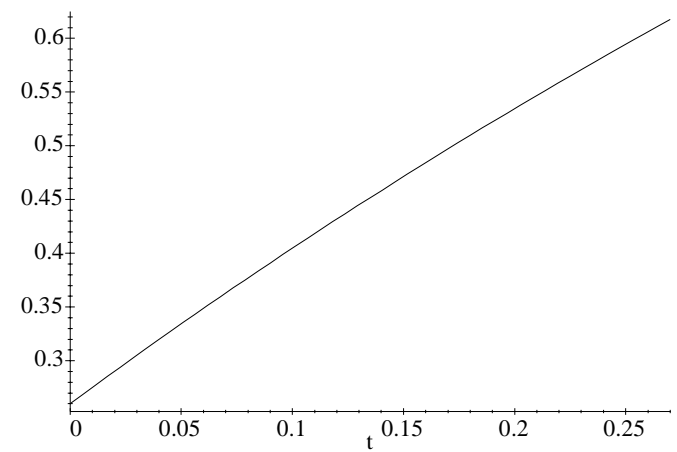

Graph 2: Tariff reduction and discount rates $(c=0.1)$

Proposition 4 As tariffs fall, bilateral agreements become easier to enforce. Multilateral tariff reduction can make a bilateral agreement that was infeasible before the reduction, feasible.

PTAs become easier to enforce when tariffs are low because tariffs influence the welfare from cooperation, the gain from a one shot deviation, and the welfare in the punishment equilibrium, which all affect enforceability. From the previous section, we know that, at low tariff levels, the benefit from participating in a PTA is high. Therefore, at low tariff levels, the incentive to comply is greater than at high tariff levels. Welfare from deviating from the PTA is increasing in the tariff level, which also makes complying easier at low tariff levels. The logic is that the expansion in domestic profits and tariff revenue, which results from imposing the optimal tariff on $Y$, is greater when the tariff on $Z$ is large. The punishment, however, is less severe when external tariffs are low, making it more difficult to enforce a PTA. The intuition is that the complementarity effect of tariffs moderates the feasible tariff threat when external tariffs are low. Still, as tariffs fall, the effect on the incentive to comply and the effect on the incentive to deviate outweigh the punishment effect, ensuring that the cutoff discount rate is declining in the tariff level. 


\subsubsection{Enforceability of a customs union or a free trade area at the Nash}

Next we solve for the cutoff discount rate starting from optimal tariff equilibrium. The gain from cooperating is slightly different in this case since countries in a customs union or a free trade area do not have the same optimal tariff as individual countries. Starting from trade war, the condition for a customs union to be feasible is:

$$
W\left(t^{n}, t^{n}, 0, t^{c u}, t^{n}, t^{n}\right)+\sum_{\tau=1}^{\infty} W\left(t^{n}, t^{n}, t^{n}, t^{n}, t^{n}, t^{n}\right) \delta^{\tau} \leq \sum_{\tau=0}^{\infty} W\left(0, t^{c u}, 0, t^{c u}, t^{n}, t^{n}\right) \delta^{\tau}
$$

The first term on the left hand side is the gain from deviating for one period and charging the Nash tariff to both of the other countries (since there is no agreement with the third country), while the partner country complies. The second term is the punishment phase. The right hand side is the gain from complying and charging the optimal customs union external tariff to the non-member and no tariff to the partner. Plugging $t^{c u}, t^{n}$, and equation (4) into equation (15) and solving, we find that in order to achieve a customs union in one step from the Nash, it must be the case that: $\delta \geq \frac{1890}{3239}=0.58$

The same approach can be used to solve for the cutoff discount rate needed in order for a free trade area to be feasible. The comparable condition is:

$$
W\left(t^{n}, t^{n}, 0, t^{f t}, t^{n}, t^{n}\right)+\sum_{\tau=1}^{\infty} W\left(t^{n}, t^{n}, t^{n}, t^{n}, t^{n}, t^{n}\right) \delta^{\tau} \leq \sum_{\tau=0}^{\infty} W\left(0, t^{f t}, 0, t^{f t}, t^{n}, t^{n}\right) \delta^{\tau}
$$

Plugging $t^{f t}, t^{n}$, and equation (4) into equation (16), it reduces to: $\delta \geq \frac{70}{117}=0.60$.

A customs union is easier to enforce than a free trade agreement. This is a result of the difference in external tariffs. The gain from complying with zero bilateral tariffs is higher under the customs union optimal tariff than under the free trade area optimal tariff, since a customs union internalizes the positive effect on partner country profits. 


\subsection{Multilateral free trade}

In this section, we examine the desirability and enforceability of achieving free trade.

\subsubsection{Incentive constraint}

Free trade is desirable if it leads to an expansion in welfare.

$$
W^{F T}(0,0,0,0,0,0) \geq W(t, t, t, t, t, t)
$$

From equation (4), the gain in welfare from moving to free trade, $W^{F T}$, given the tariff level is $t$, is:

$$
W^{F T}-W=\frac{1-c+t}{8 a}>0
$$

Hence, there are gains from moving to free trade for all positive symmetric tariffs. The gain in welfare is purely an efficiency gain (the shaded area in Figure 3). As tariffs fall, we get closer to the efficient outcome, implying that the welfare gain from the move to free trade is smaller at low tariff levels.

\subsubsection{Enforceability}

Multilateral free trade is sustainable only if:

$$
W\left(t^{n}, t^{n}, 0,0,0,0\right)+\sum_{\tau=1}^{\infty} W\left(t^{n}, t^{n}, t^{n}, t^{n}, t^{n}, t^{n}\right) \delta^{\tau} \leq \sum_{\tau=0}^{\infty} W(0,0,0,0,0,0) \delta^{\tau}
$$

The first term on the left hand side of (19) is the welfare from deviating for one period, the second term is the discounted welfare during the Nash punishment phase, and the right hand side represents the present discounted value of complying with free trade forever. Solving, condition (19) yields:

$$
\delta \geq \frac{15}{28}=0.54 .
$$




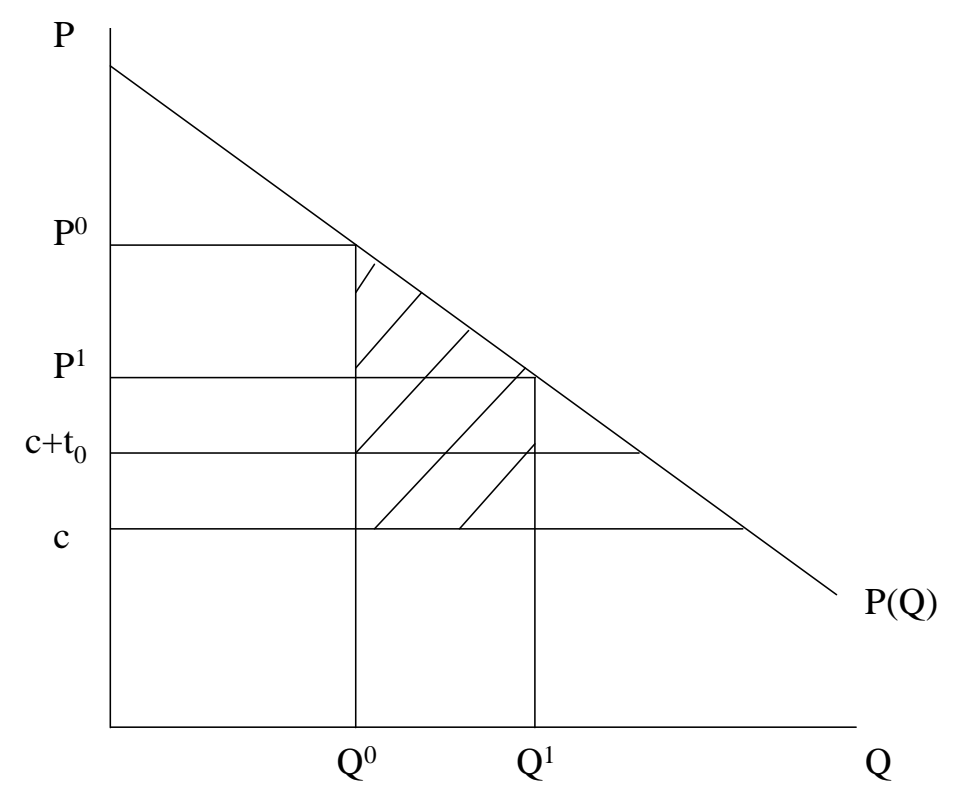

Figure 3: Multilateral tariff reduction

If $\delta<0.54$ free trade cannot be achieved. The discount rate needed to support free trade is not dependent on the given tariff level, $t$, implying tariff reduction has no effect on the ability to achieve free trade.

Proposition 5 Tariff reduction does not affect the enforceability of multilateral free trade.

The discount rate needed to enforce either a customs union or a free trade agreement from the optimal tariff equilibrium is higher than the discount rate needed to achieve multilateral free trade. Hence, if free trade is not feasible neither is a bilateral agreement, given countries set tariffs optimally. However, if countries can cooperate on partial tariff reduction, a PTA may become feasible as the result of the tariff reduction.

Proposition 6 If all discount rates are below the cutoff level needed to achieve multilateral free trade and no multilateral cooperation has been achieved then a PTA is not enforceable (initially). 


\section{Conclusion}

While the conventional wisdom is that the recent proliferation of PTAs is in part a response to the failure of the GATT, this model suggests the opposite. That is, many of the current partnerships may actually be a result of the success of the GATT in lowering tariffs. According to this model, the decline in tariffs over the last 40 years has increased both the incentive to join a PTA and the likelihood that the agreement is sustainable. We show that at low tariff levels, market share gains from regional agreements can dominate the loss in competition to such an extent that they are preferred by member countries to free trade. Moreover, since the gain from complying with a PTA is greater at a low tariff level, difficulties in enforcing PTAs ease as tariffs fall. As a result, every round of multilateral tariff reductions should be met with an expansion in the number of PTAs. 


\section{References}

[1] Bagwell, K. and R. Staiger, 1990. A Theory of Managed Trade. American Economic Review, September, pp. 779-795.

[2] Bagwell, K. and R. Staiger, 1997a. Regionalism and Multilateral Tariff Cooperation. In: John Piggott and Alan Woodland (Editors), International Trade Policy and the Pacific Rim, London: McMillan.

[3] Bagwell, K. and R. Staiger, 1997b. Multilateral Tariff Cooperation During the Formation of a Customs Union. Journal of International Economics, February, pp. 91-123.

[4] Baldwin, R., 1995, A Domino Theory of Regionalism. In: R. Baldwin, P. Haaparanta and J. Kiander (Editors), Expanding Membership of the European Union (Cambridge University Press).

[5] Bhagwati, J. and A. Panagariya, 1996. Preferential Trading Areas and Multilateralism: Strangers Friends or Foes? In: J. Bhagwati and A. Panagariya (Editors), The Economics of Preferential Trade Agreements (AEI Press, Washington DC).

[6] Bond, E., and C. Syropoulos, 1996a. The Size of Trading Blocks Market Power and World Welfare Effects. Journal of International Economics 40, pp. 411-437.

[7] Bond, E., and C. Syropoulos, 1996b. Trading Blocks and the Sustainability of Inter-regional Cooperation. In: Cazoneri, Ethier, and Grilli (Editors), The New Transatlantic Economy (Cambridge University Press).

[8] Bond, E., C. Syropoulos, and A. Winters, 1995. Deepening Regional Integration and Multilateral Trade Agreements. Mimeo. 
[9] Brander J., and Krugman, 1983. A 'Reciprocal Dumping' Model of International Trade. Journal of International Economics 15, November, pp. 313-323.

[10] Brander J. and B. Spencer, 1984. Tariff Protection and Imperfect Competition. In: H. Kierzkowski (Editor), Monopolistic Competition and International Trade (Oxford University Press).

[11] Ethier, Wilfred, 1996. Regionalism in a Multilateral World. Mimeo.

[12] Grossman, G. and E. Helpman, 1995. The Politics of Free Trade Agreements. American Economic Review, September, pp. 667-690.

[13] Kennan, J. and R. Riezman, 1990. Optimal Tariff Equilibria with Customs Unions. Canadian Journal of Economics, February, pp. 70-83.

[14] Krishna, P., 1998. Regionalism and Multilateralism: A Political Economy Approach. Quarterly Journal of Economics, February, pp. 227-251.

[15] Krugman, P., 1992. Is Bilateralism Bad? In: Helpman and Razin (Editors), International Trade and Trade Policy, (MIT Press).

[16] Levy, P., 1997. A Political-Economic Analysis of Free-Trade Agreements. American Economic Review, September, pp. 506-19.

[17] Richardson, M. 1993. Endogenous Protection and Trade Diversion. Journal of International Economics 34, pp. 309-324.

[18] Yi, S. 1996. Endogenous Formation of Customs Unions Under Imperfect Competition: Open Regionalism is Good. Journal of International Economics, 41, pp. 153-177. 